Rendi Ariyanto Sinanto, Sitti Nur Djannah "Efektivitas Cuci Tangan Menggunakan Sabun Sebagai Upaya Pencegahan Infeksi : Tinjauan Literatur" (hal 96-111)

Received

06 Juni 2020
Revisied

28 Juli 2020
Acceptep

15 Oktober 2020

\title{
EFEKTIVITAS CUCI TANGAN MENGGUNAKAN SABUN SEBAGAI UPAYA PENCEGAHAN INFEKSI : TINJAUAN LITERATUR
}

\author{
Rendi Ariyanto Sinanto ${ }^{1}$, Sitti Nur Djannah ${ }^{2}$ \\ 1) Magister Kesehatan Masyarakat Universitas Ahmad Dahlan \\ 2) Universitas Ahmad Dahlan \\ E-mail : rendisinanto@gmail.com
}

\begin{abstract}
ABSTRAK
Indonesia merupakan negara yang gencar melakukan peningkatan kesehatan masyarakat, pemerintah mencanangkan program cuci tangan pakai sabun yang berguna meningkatkan kebersihan sehingga terhindar dari penyakit. Tujuan penelitian ini yaitu untuk mengetahui bagaimana efektifitas cuci tangan pakai sabun/hand hygiene dalam pencegahan infeksi. Metode penelitian yang digunakan adalah literature review dengan mengambil sumber data pada jurnal garuda ristekdikti yang diterbitkan dalam kurun waktu tahun 2015 sampai dengan 2020 yang diunduh pada tanggal 3 Juli sampai 10 Juli 2020. Setelah dilakukan seleksi dan identifikasi sesuai dengan kriteria inklusi, terdapat 8 artikel yang direview. Hasil penelitian didapatkan bahwa cuci tangan pakai sabun/hand hygiene dalam pencegahan infeksi sangat efektif, terbukti bahwa cuci tangan pakai sabun dapat menurunkan resiko infeksi. Cuci tangan pakai sabun merupakan pilar dari sanitasi total berbasis masyarakat yang didalamnya terdapat cuci tangan enam langkah. Penggunaan hand sanitizer dan sabun dapat menurunkan jumlah koloni bakteri pada tangan, dan sanitizer yang mengandung alkohol $70 \%$ sangat efektif menurunkan jumlah kuman.
\end{abstract}

Kata Kunci : CTPS, cuci tangan, hand hygiene, pencegahan infeksi.

\section{ABSTRACT}

Indonesia is a country that aggressively promotes public health, the government has aunched a program of washing hands with soap that is useful to improve hygiene so as to avoid disease.The purpose of this study was to study the effectiveness of washing hands with soap / hand hygiene in dealing with infections. The research method used is a literature review by taking data sources in the Garuda Ristekdikti journal published in the period 2015 to 2020 which was downloaded from July 3 to July 10, 2020. After being carried out and adjusted according to the request for inclusion, there are 8 articles that are Insightful. The results showed that washing hands with soap / hand hygiene in the prevention of infection is very proven, proven washing hands with soap can eliminate the risk of infection. Washing hands with soap is a pillar of the total community in which a six-step hand washing is needed. The use of hand sanitizers and soaps can reduce the number of bacteria on the hands, and cleaners that contain alcohol $70 \%$ are very effective at reducing the number of germs.

Keywords: CTPS, hand washing, hand hygiene, prevention of infection. 
Jurnal Kesehatan Karya Husada, Vol 8 No 2 Tahun 2020

PISSN 2337649X/EISSN 2655-8874

Rendi Ariyanto Sinanto, Sitti Nur Djannah "Efektivitas Cuci Tangan Menggunakan Sabun Sebagai Upaya

Pencegahan Infeksi : Tinjauan Literatur” (hal 96-111)

\section{PENDAHULUAN}

Menurut Undang-Undang Nomor 36

Tahun 2009 Tentang Kesehatan, menyatakan bahwa kesehatan merupakan keadaan sehat baik secara fisik, mental, sosial dan spiritual, sehingga seseorang dapat hidup produktif. Indonesia merupakan salah satu negara yang gencar dalam melakukan peningkatan kesehatan masyarakat, melalui kementerian kesehatan pemerintah mencanangkan program Perilaku Hidup Bersih dan Sehat (PHBS) sebagai sarana peningkatan kesehatan bagi masyarakat.

Dalam program PHBS terdapat 10 program penting yang dilakukan dan diberikan kepada masyarakat yang salah satunya adalah mencuci tangan atau menjaga kebersihan tangan (hand hygiene), kebersihan tangan (hand hygiene) merupakan cara untuk meningkatkan kebersihan diri individu (Kemenkes, 2016).

Menurut penelitian yang dilakukan Desiyanto dan Djannah (2013), hand hygiene merupakan istilah dari tindakan mencuci tangan yang mana di artikan sebagai tindakan sanitasi dengan membersihkan jemari menggunakan air, sabun ataupun cairan lainnya dengan tujuan menjadi bersih. Sedangkan menurut Loffler \& Gastmeter (2009) dalam Susilo (2015), hand hygiene penting dilakukan sebagai salah satu cara untuk mengurangi angka kejadian infeksi nosokomial (INOS).

Sesuai dengan akibat yang ditimbulkan dari pola hidup yang kurang baik dalam menjaga kebersihan tangan seperti diare, dan seperti yang terjadi saat ini yaitu infeksi covid-19. Maka upaya promosi kesehatan kepada masyarakat sangat penting dilakukan untuk mencegah infeksi, karena hal ini sesuai dengan pembangunan kesehatan yang sudah dilakukan pemerintah.

Pembangunan kesehatan merupakan upaya dalam meningkatkan kemampuan masyarakat untuk hidup sehat, dalam mendukung upaya tersebut maka masyarakat harus dibekali dengan pengetahuan tentang cara hidup sehat. Pemerintah melalui Kementerian Kesehatan telah mencanangkan program promosi kesehatan dalam pencegahan segala macam penyakit, sehingga mempercepat pencapaian derajat 
Jurnal Kesehatan Karya Husada, Vol 8 No 2 Tahun 2020

PISSN 2337649X/EISSN 2655-8874

Rendi Ariyanto Sinanto, Sitti Nur Djannah "Efektivitas Cuci Tangan Menggunakan Sabun Sebagai Upaya

Pencegahan Infeksi : Tinjauan Literatur" (hal 96-111)

kesehatan yang optimal bagi

masyarakat (Kemenkes, 2016).

Program promosi kesehatan yang sangat penting dilakukan saat ini dalam upaya mencegah infeksi menurut Kementerian Kesehatan salah satunya bisa dilakukan dengan cuci tangan pakai sabun/hand hygiene, cuci tangan menggunakan air bersih dengan sabun merupakan cara untuk meningkatkan kebersihan diri individu (Kemenkes, 2020).

Saat ini program pemerintah tentang CTPS berjalan dengan baik, dibuktikan dengan adanya anjuran pemerintah pada masyarakat untuk selalu mencuci tangan dalam mencegah infeksi, terutama dalam hal pencegahan covid-19 yang sedang berlangsung sekarang (Setkab, 2020). Cuci tangan pakai sabun merupakan perilaku pencegahan covid-19 yang efektif, hal ini dibuktikan dengan hasil penelitian Nakoe dan Mohamad, (2020), didapatkan bahwa cuci tangan pakai sabun lebih efektif dalam membunuh virus.

Perilaku hidup bersih dan sehat merupakan salah satu strategi dalam pencegahan penyebaran infeksi covid19 yang efektif dan mudah dilakukan

pada semua lapisan masyarakat yang didalamnya terdapat cuci tangan pakai sabun (Karo, 2020). Mencuci tangan sendiri diartikan sebagai perilaku atau usaha individu dalam memelihara kesehatan agar tidak sakit (Notoatmodjo,2012).

Berdasarkan uraian diatas maka peneliti merumuskan masalah penelitian yaitu bagaimanakah efektifitas cuci tangan pakai sabun/hand hygiene dalam pencegahan infeksi?. Secara umum penelitian ini bertujuan untuk mengetahui bagaimana efektifitas cuci tangan pakai sabun/hand hygiene dalam pencegahan infeksi.

Penelitian ini akan mendapatkan informasi tentang efektifitas cuci tangan pakai sabun/hand hygiene dalam pencegahan infeksi, sehingga peneliti dapat memberikan program promosi kesehatan, agar dapat meningkatkan pengetahuan, dan keterampilan kepada masyarakat dalam pencegahan infeksi tersebut dengan cuci tangan pakai sabun.

\section{METODE}

Penelitian ini dilakukan dengan menggunakan metode literature review pada tangal 3 sampai dengan 
Jurnal Kesehatan Karya Husada, Vol 8 No 2 Tahun 2020

PISSN 2337649X/EISSN 2655-8874

Rendi Ariyanto Sinanto, Sitti Nur Djannah "Efektivitas Cuci Tangan Menggunakan Sabun Sebagai Upaya

Pencegahan Infeksi : Tinjauan Literatur” (hal 96-111)

tanggal 10 Juli 2020 dengan pelaporan

naratif. Penelitian dilakukan terhadap

artikel

pada

http://garuda.ristekdikti.go.id yang

diterbitkan dalam kurun waktu tahun

2015 sampai dengan 2020. Berikut alur penelitian disajikan dalam Skema 1.



Urutan proses yang dilakukan dalam penelitian ini : 1) Identifikasi pertanyaan penelitian,

Mengembangkan protokol penelitian,

3) Menetapkan lokasi database yang

dijadikan wilayah pencarian, 4)

Seleksi hasil penelitian yang relevan,

5) Melakukan pemilihan terhadap

hasil penelitian yang berkualitas, 6)

Ekstraksi data dari studi individual, 7)

Sintesis hasil, 8) Penyajian hasil.
(Perry \& Hammond, 2002 dalam

Siswanto (2012).

Kriteria Kelayakan

1. Kriteria inklusi

a. Penelitian dilakukan di Indonesia dengan rentan waktu tahun 20152020

b. Artikel yang dipublikasi di http://garuda.ristekdikti.go.id

c. Artikel membahas tentang efektifitas cuci tangan pakai sabun/hand hygiene dalam pencegahan infeksi.

2. Kriteria eksklusi

a. Artikel yang tidak bisa di download.

b. Artikel yang abstrak tidak jelas.

3. Seleksi artikel yang diperoleh Tahapan seleksi dilakukan melalui proses berikut :

a. Penetapan kata kunci

Penelusuran terhadap artikel yang menyelidiki permasalahan sesuai dengan topik penelitian, dengan menggunakan kata kunci sebagai berikut: CTPS, hand hygiene, pencegahan infeksi, efektifitas cuci tangan, kebersihan tangan, cuci tangan pakai sabun. 
Jurnal Kesehatan Karya Husada, Vol 8 No 2 Tahun 2020

PISSN 2337649X/EISSN 2655-8874

Rendi Ariyanto Sinanto, Sitti Nur Djannah "Efektivitas Cuci Tangan Menggunakan Sabun Sebagai Upaya

Pencegahan Infeksi : Tinjauan Literatur” (hal 96-111)

b. Melakukan eksplorasi judul, terdapat 165 artikel yang disingkirkan abstrak dilakukan berdasarkan kriteria kelayakan

c. Melakukan eksplorasi isi artikel karena masuk didalam kriteria ekslusi, dan terdapat 8 artikel yang masuk pada artikel yang eligible.

d. Melakukan scanning terhadap daftar pustaka untuk mengeksplorasi keterkaitan artikel dengan penelitian yang dilakukan.

4. Proses Pengumpulan Data Pengumpulan data dilakukan secara manual menggunakan formulir yang terdiri dari : penulis, judul artikel, nama jurnal atau konferensi, serta tahun terbit.

5. Jenis Data

Jenis data yang diambil adalah : judul penelitian, peneliti, nama jurnal atau konferensi dan perguruan tinggi, serta hasil penelitian yang relevan dengan permasalahan penelitian.

\section{HASIL DAN PEMBAHASAN}

Sesuai penelusuran pada database ditemukan 173 artikel yang relevan dengan kata kunci, keseluruhan artikel ditulis dalam bahasa Indonesia, penelitian dilakukan dalam periode 2015-2020. Berdasarkan jumlah artikel yang ditemukan, 
Jurnal Kesehatan Karya Husada, Vol 8 No 2 Tahun 2020

PISSN 2337649X/EISSN 2655-8874

Rendi Ariyanto Sinanto, Sitti Nur Djannah "Efektivitas Cuci Tangan Menggunakan Sabun Sebagai Upaya Pencegahan Infeksi : Tinjauan Literatur" (hal 96-111)

Tabel 1. Hasil penclitian

\begin{tabular}{|c|c|}
\hline Penulis/Judul & Hasil \\
\hline $\begin{array}{l}\text { Nur, dkk (2020) } \\
\text { dengan judul } \\
\text { "Pengarnuh } \\
\text { Pendidikan } \\
\text { Kesehatan } \\
\text { Menggunakan } \\
\text { Team Games } \\
\text { Tournanent (TGT) } \\
\text { Terhadap } \\
\text { Pengetahuan dan } \\
\text { Sikap Cuci } \\
\text { Tangan Pahai } \\
\text { Sabun Pada } \\
\text { Pencegahan } \\
\text { Penyakit Diare di } \\
\text { Sisun Kelas } 5 \\
\text { Sekolah Dasar" }\end{array}$ & $\begin{array}{l}\text { Didapatkan } \\
\text { bahwa ada } \\
\text { penguruh yang } \\
\text { signifikan untara } \\
\text { pengaruh } \\
\text { pendidikan } \\
\text { keschatan } \\
\text { mengrunakan } \\
\text { Team Games } \\
\text { Toumament } \\
\text { terhadap } \\
\text { pengetahuan dan } \\
\text { sikap cuci tangan } \\
\text { pakai sabun pada } \\
\text { pencegahan } \\
\text { penyulit diare di } \\
\text { siswa kelas } 5 \text { SDN } \\
\text { Kedungkandang } 1 \\
\text { Kota Malang. }\end{array}$ \\
\hline $\begin{array}{l}\text { Primayana, dkk } \\
\text { (2018) dengan } \\
\text { judul } \\
\text { "Perbandingan } \\
\text { Efektifitas Cici } \\
\text { Tangan Tujuh } \\
\text { Langkah Dengan } \\
\text { Air Dan Dengan }\end{array}$ & $\begin{array}{l}\text { Menunjukkan } \\
\text { babwa terdapat } \\
\text { perbodaan yang } \\
\text { signifikan antarn } \\
\text { cfektifitas cuci } \\
\text { tangan dengan air } \\
\text { dan sabun dalam } \\
\text { mengurungi }\end{array}$ \\
\hline
\end{tabular}

\begin{tabular}{|c|c|}
\hline  & $\begin{array}{l}\text { jumlah kalont } \\
\text { bakien }\end{array}$ \\
\hline 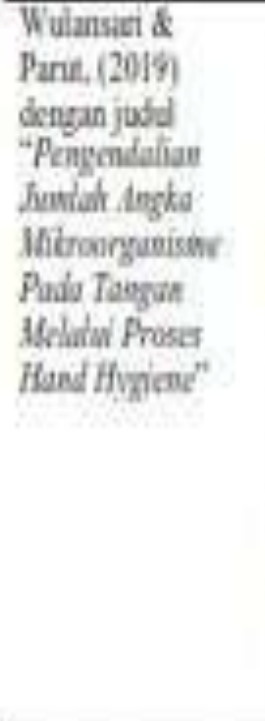 & 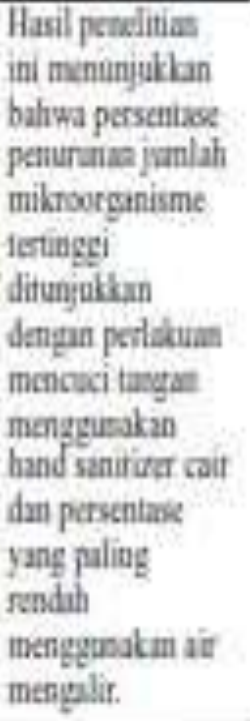 \\
\hline Penulis.Judul & Hasal \\
\hline 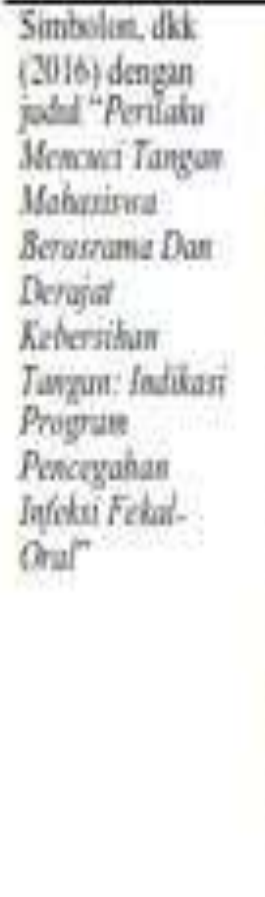 & 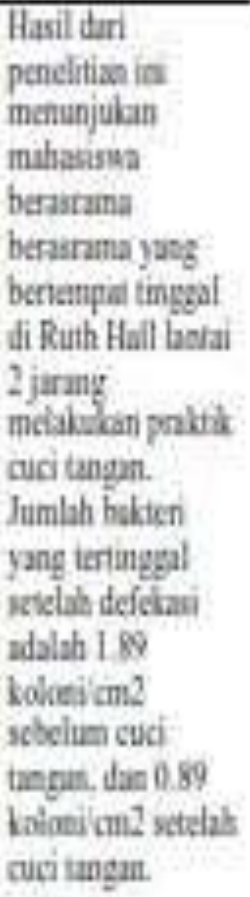 \\
\hline
\end{tabular}


Jurnal Kesehatan Karya Husada, Vol 8 No 2 Tahun 2020

PISSN 2337649X/EISSN 2655-8874

Rendi Ariyanto Sinanto, Sitti Nur Djannah "Efektivitas Cuci Tangan Menggunakan Sabun Sebagai Upaya

Pencegahan Infeksi : Tinjauan Literatur” (hal 96-111)

\begin{tabular}{|c|c|}
\hline 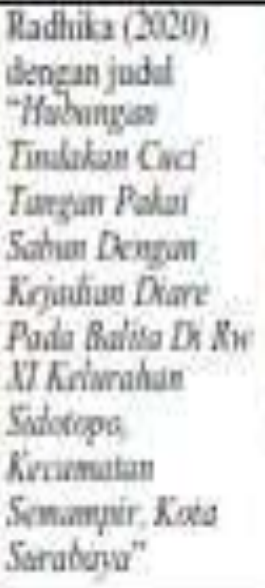 & 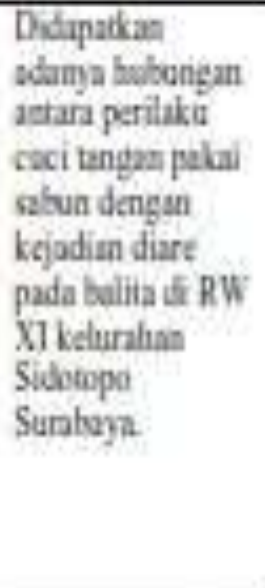 \\
\hline 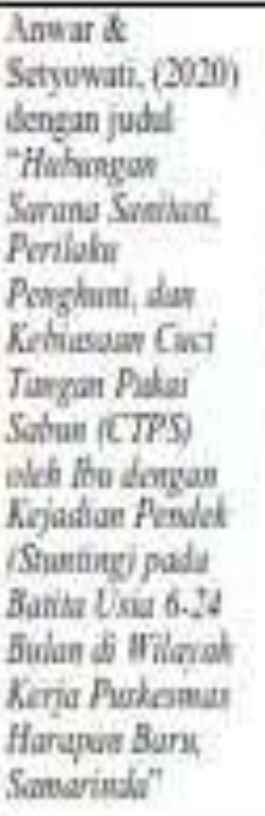 & 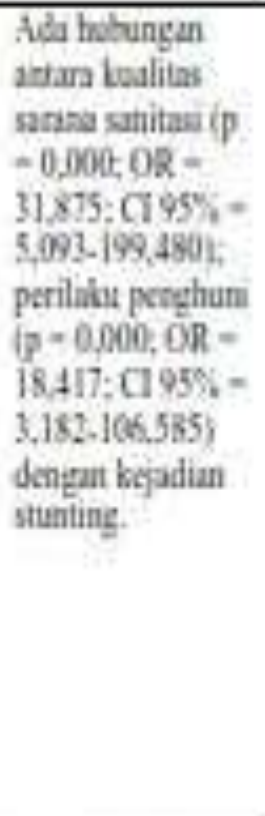 \\
\hline 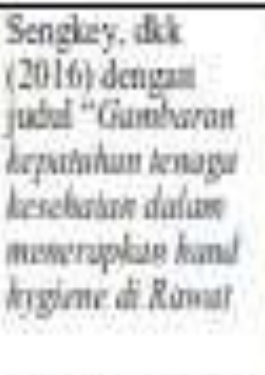 & 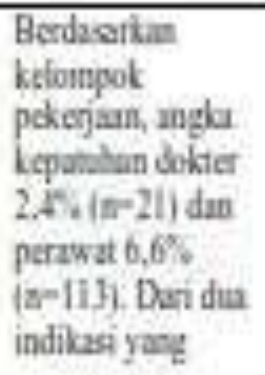 \\
\hline PenulinJudal & กับ \\
\hline $\begin{array}{l}\text { Thop RETP Prot } \\
\text { D. R. D. Kandow } \\
\text { Monada" }\end{array}$ & 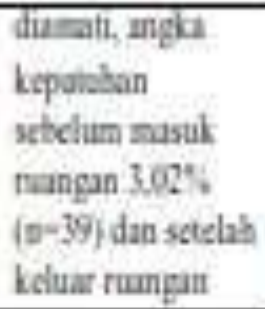 \\
\hline
\end{tabular}

\begin{tabular}{|c|c|}
\hline &  \\
\hline 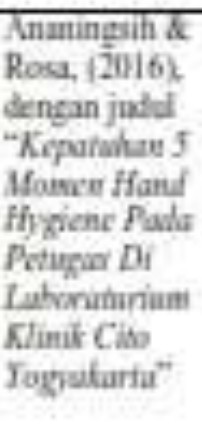 & 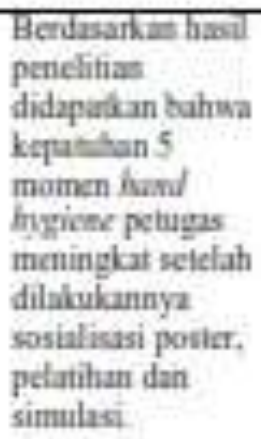 \\
\hline
\end{tabular}

Hasil review terhadap artikel yang terseleksi menunjukan bahwa efektifitas cuci tangan pakai sabun/hand hygiene dalam pencegahan infeksi adalah sangat efektif, sesuai penelitian Nur, dkk (2020), didapatkan bahwa ada pengaruh yang signifikan antara pengaruh pendidikan kesehatan menggunakan Team Games Tournament terhadap pengetahuan dan sikap cuci tangan pakai sabun pada pencegahan penyakit diare di siswa kelas 5 SDN Kedungkandang 1 Kota Malang. 
Jurnal Kesehatan Karya Husada, Vol 8 No 2 Tahun 2020

PISSN 2337649X/EISSN 2655-8874

Rendi Ariyanto Sinanto, Sitti Nur Djannah "Efektivitas Cuci Tangan Menggunakan Sabun Sebagai Upaya

Pencegahan Infeksi : Tinjauan Literatur" (hal 96-111)

Menurut Notoatmodjo (2012),

pengetahuan adalah hasil

dari penginderaan seseorang terhadap

suatu objek melalui panca indera

manusia, sedangkan

menuru

Tarwoto dan Wartonah (2004) dalam

(Sekarwati, 2017), pengetahuan merupakan salah satu faktor yang mempengaruhi perilaku mencuci tangan. Menurut penelitian Wati, dkk (2017), sikap adalah reaksi individu terhadap suatu stimulus maupun objek, sikap terbentuk dari beberapa faktor yaitu pengalaman pribadi, budaya, pengaruh orang lain yang dianggap penting, media masa, dan emosi dalam diri seseorang.

Hasil penelitian tersebut sejalan dengan teori menurut Notoatmodjo (2012), yang menyatakan sikap adalah respon seseorang yang melibatkan emosi yang bersangkutan (setuju tidak setuju, atau baik tidak baik). Berdasarkan uraian diatas dapat menjadi bukti bahwa pengetahuan dan sikap merupakan faktor penting dalam diri seseorang untuk melakukan tindakan cuci tangan pakai sabun dalam pencegahan infeksi.

Menurut Primayana, dkk (2018), didapatkan bahwa terdapat perbedaan yang signifikan antara efektifitas cuci

tangan dengan air dan sabun dalam mengurangi jumlah koloni bakteri. Menurut Notoatmodjo (2012), mencuci tangan sendiri diartikan sebagai perilaku atau usaha individu dalam memelihara kesehatan agar tidak sakit. Sedangkan menurut Peraturan Menteri Kesehatan Nomor 3 Tahun 2014 Tentang Sanitasi Total Berbasis Masyarakat pada pasal 3 menyebutkan bahwa mencuci tangan merupakan pilar dari sanitasi total berbasis masyarakat, yang didalamnya terdapat cuci tangan enam langkah yang baik dan benar.

Hal tersebut sesuai dengan pernyataan dari Kementerian Kesehatan bahwa enam langkah cuci tangan pakai sabun pada air mengalir efektif dalam pencegahan penyakit. Menurut hasil penelitian Wulansari dan Parut, (2019) menunjukkan bahwa persentase penurunan jumlah mikroorganisme tertinggi ditunjukkan dengan perlakuan mencuci tangan menggunakan hand sanitizer cair dan persentase yang paling rendah menggunakan air mengalir.

Menurut Hariwibowo dan Larasati (2020), didapatkan antiseptik efektif digunakan untuk mencegah penularan covid-19. Sesuai hasil penelitian 
Jurnal Kesehatan Karya Husada, Vol 8 No 2 Tahun 2020

PISSN 2337649X/EISSN 2655-8874

Rendi Ariyanto Sinanto, Sitti Nur Djannah "Efektivitas Cuci Tangan Menggunakan Sabun Sebagai Upaya Pencegahan Infeksi : Tinjauan Literatur" (hal 96-111)

tersebut dapat disimpulkan bahwa antiseptik sangat efektif dan terbukti dapat mengurangi resiko terinfeksi. Hasil yang sama juga ditemukan pada penelitian Wahyuni, et al (2017), didapatkan bahwa penggunaan gel hand sanitizer dan tisu basah antiseptik dapat menurunkan jumlah koloni kuman di tangan, hasil penelitian ini didukung dengan hasil penelitan dari Norfai dan Abdullah (2018), bahwa hand sanitizer yang mengandung bahan alkohol 70\% sangat efektif dalam menurunkan jumlah kuman.

Berdasarkan hasil penelitian Simbolon, dkk (2016), jumlah bakteri yang tertinggal setelah defekasi adalah 1.89 koloni/cm2 sebelum cuci tangan, dan 0.89 koloni $/ \mathrm{cm} 2$ setelah cuci tangan. Sesuai hasil tersebut maka terdapat perbedaan yang signifikan pada jumlah bakteri saat sebelum dan sesudah mencuci tangan, hal ini sejalan dengan hasil penelitian menurut Radhika, (2020), didapatkan bahwa adanya hubungan antara perilaku cuci tangan pakai sabun dengan kejadian diare pada balita, cuci tangan adalah tindakan yang dilakukan untuk mencegah penyakit.
Menurut Ruíz (2015), bahwa ada hubungan kepatuhan cuci tangan enam langkah dengan kejadian phlebitis, yang artinya cuci tangan enam langkah pakai sabun dengan air mengalir merupakan cara yang baik dan benar dalam upaya pencegahan penyakit.

Menurut Anwar dan Setyowati (2020), didapatkan ada hubungan kualitas sarana sanitasi, perilaku penghuni dalam cuci tangan pakai sabun dengan kejadian stunting, terkait sanitasi lingkungan yang baik didapatkan hasil yang sama dengan penelitian Setyowatiningsih dan Surati (2017), didapatkan bahwa sebagian besar pemulung di TPS Jatibarang Kabupaten Semarang sudah menerapkan hygiene sanitasi lingkungan dengan baik sehingga kejadian infeksi kecacingan pada pemulung di TPS Jatibarang 100\% negatif.

Kemudian terkait perilaku, menurut Notoatmodjo (2012), perilaku secara umum merupakan respon/reaksi seorang individu terhadap stimulus yang berasal dari luar maupun dari dalam dirinya, sedangkan perilaku kesehatan adalah respon terhadap stimulus atau objek yang berkaitan dengan sehat sakit, penyakit, serta 
Jurnal Kesehatan Karya Husada, Vol 8 No 2 Tahun 2020

PISSN 2337649X/EISSN 2655-8874

Rendi Ariyanto Sinanto, Sitti Nur Djannah "Efektivitas Cuci Tangan Menggunakan Sabun Sebagai Upaya

Pencegahan Infeksi : Tinjauan Literatur" (hal 96-111)

faktor yang mempengaruhi kesehatan seperti lingkungan, makanan, minuman, dan pelayanan kesehatan.

Perilaku seseorang dipengaruhi oleh determinan perilaku, yang terdiri dari dua faktor, yang pertama yaitu faktor internal atau karakteristik bawaan, seperti tingkat kecerdasan, dan tingkat emosional. Kemudian yang kedua adalah fakor eksternal seperti lingkungan, sosial, budaya, ekonomi, politik dan sebagainya (Notoatmodjo, 2012). Sesuai uraian diatas, artinya sanitasi lingkungan dan perilaku yang baik akan menurunkan resiko terinfeksi penyakit.

Pelaksanaan cuci tangan pakai sabun pada masyarakat saat ini sangat baik, sesuai penelitian Elidahanum dan Husni (2019), didapatkan bahwa kemampuan siswa mempraktekkan tujuh langkah cuci tangan pakai sabun dengan baik dan benar setelah diberikan demonstrasi dan edukasi CTPS. Perilaku hidup bersih dan sehat melalui cuci tangan mengalami peningkatan yang signifikan pada masyarakat (Yesi dkk, 2018).

Terdapat lima faktor yang berhubungan dengan mencuci tangan dengan sabun pada siswa, diantanya yaitu pengetahuan, sikap, dukungan guru, dukungan teman, dan ketersediaan mencuci tangan dengan sabun (Mukminah, 2016). Terdapat penelitian yang menyatakan bahwa ada hubungan yang signifikan antara personal hygiene (cuci tangan pakai sabun) dengan kejadian penyakit cacingan, hal ini membuktikan bahwa adanya korelasi antara cuci tangan dalam pencegahan infeksi (Zubaidi dkk, 2017).

Hal yang sama juga ditemui dalam penelitian Utomo (2013), yang menyatakan ada hubungan antara perilaku cuci tangan pakai sabun dengan kejadian diare pada anak usia sekolah.

Saat ini penyakit infeksi yang menyerang dunia termaksud Indonesia adalah covid-19 yang dapat menyerang dengan cepat dan mudah, cara penularan dari virus ini yaitu melalui droplet/tetesan kecil dari hidung, dan mulut ketika bersin atau batuk. Ketika droplet tersebut melekat pada benda disekitar kita, maka kita mempunyai resiko tinggi untuk tertular (Kemenkes,2020).

Program promosi kesehatan yang sangat penting dilakukan saat ini dalam upaya mencegah covid-19 menurut Kementerian Kesehatan salah 
Jurnal Kesehatan Karya Husada, Vol 8 No 2 Tahun 2020

PISSN 2337649X/EISSN 2655-8874

Rendi Ariyanto Sinanto, Sitti Nur Djannah "Efektivitas Cuci Tangan Menggunakan Sabun Sebagai Upaya

Pencegahan Infeksi : Tinjauan Literatur" (hal 96-111)

satunya bisa dilakukan dengan cuci tangan pakai sabun/hand hygiene, cuci tangan menggunakan air bersih dengan sabun merupakan cara untuk meningkatkan kebersihan diri individu (Kemenkes,2020).

Hal tersebut sesuai dengan hasil penelitian Nakoe dan Mohamad (2020), didapatkan bahwa cuci tangan pakai sabun lebih efektif dalam membunuh virus. Menurut Peraturan Menteri Kesehatan Nomor 3 Tahun 2014 Tentang Sanitasi Total Berbasis Masyarakat pada pasal 3 menyebutkan cuci tangan pakai sabun merupakan pilar dari sanitasi total berbasis masyarakat, yang didalamnya terdapat cuci tangan enam langkah yang baik dan benar.

Cuci tangan yang baik dan benar sering diterapkan pada fasilitas kesehatan, hal tersebut didukung dengan hasil penelitian Sengkey,dkk (2016), bahwa berdasarkan kelompok pekerjaan, angka kepatuhan dokter $2,4 \% \quad(n=21)$ dan perawat $6,6 \%$ $(\mathrm{n}=113)$. Dari dua indikasi yang diamati, angka kepatuhan sebelum masuk ruangan $3,02 \% \quad(n=39) \quad$ dan setelah keluar ruangan 7,35\% ( $\mathrm{n}=95)$. Dapat disimpulkan bahwa tingkat kepatuhan hand hygiene tenaga kesehatan masih rendah.

Untuk meningkatkan kepatuhan dapat dilakukan dengan sosialisasi poster, pelatihan dan simulasi, hal ini sesuai dengan penelitian menurut Ananingsih dan Rosa, (2016), berdasarkan hasil penelitian didapatkan bahwa kepatuhan 5 momen hand hygiene petugas meningkat setelah dilakukannya sosialisasi poster, pelatihan dan simulasi. Hasil yang sama juga didapatkan pada penelitian Yusnita (2016), bahwa terdapat perbedaan yang signifikan terhadap pengetahuan setelah diberikan pendidikan kesehatan menggunakan poster, video dan leaflet.

Sesuai uraian tersebut maka pentingnya pengoptimalan upaya promosi kesehatan dengan memanfaatkan media sosial, poster, banner, leaflet, serta spanduk maupun billboard kepada masyarakat, dan yang tidak kalah penting adalah melakukan simulasi atau pelatihan terkait cuci tangan pakai sabun dalam pencegahan infeksi, apabila promosi kesehatan dilakukan dengan baik, maka akan terjadinya peningkatan derajat kesehatan yang optimal bagi seluruh masyarakat. 
Jurnal Kesehatan Karya Husada, Vol 8 No 2 Tahun 2020

PISSN 2337649X/EISSN 2655-8874

Rendi Ariyanto Sinanto, Sitti Nur Djannah "Efektivitas Cuci Tangan Menggunakan Sabun Sebagai Upaya

Pencegahan Infeksi : Tinjauan Literatur" (hal 96-111)

\section{SIMPULAN DAN SARAN}

Berdasarkan kajian literatur yang dilakukan maka dapat disimpulkan bahwa: Cuci tangan pakai sabun/hand hygiene dalam pencegahan infeksi adalah sangat efektif. Terbukti bahwa cuci tangan pakai sabun dapat menurunkan resiko infeksi, dalam mengimplementasikan tindakan cuci tangan pakai sabun maka pentingnya pengetahuan, sikap, dan perlaku yang baik dalam diri seseorang tentang CTPS agar terhindar dari penyakit. Cuci tangan pakai sabun merupakan pilar dari sanitasi total berbasis masyarakat yang didalamnya terdapat cuci tangan enam langkah yang baik dan benar.

Menurut hasil penelitian diatas penggunaan hand sanitizer dan sabun dapat menurunkan jumlah koloni pada tangan, dan sanitizer yang mengandung bahan alkohol $70 \%$ sangat efektif dalam menurunkan jumlah kuman. Dalam pencegahan suatu penyakit perlu adanya sanitasi lingkungan dan perilaku yang baik bagi masyarakat, perilaku kesehatan adalah respon terhadap stimulus atau objek yang berkaitan dengan sehat sakit, penyakit, serta faktor yang mempengaruhi kesehatan seperti lingkungan, makanan, minuman, dan pelayanan kesehatan.

Terkait pencegahan penyakit/infeksi, akan tercipta apabila terdapat kepatuhan cuci tangan pakai sabun yang baik pada masyarakat. Untuk pemerintah agar meningkatkan kepatuhan masyarakat dengan dilakukan promosi kesehatan dengan memanfaatkan media sosial, poster, banner, leaflet, serta spanduk maupun billboard kepada masyarakat, dan yang tidak kalah penting adalah melakukan simulasi atau pelatihan terkait cuci tangan pakai sabun dalam pencegahan infeksi.

\section{DAFTAR PUSTAKA}

Ananingsih, P. D., \& Rosa, E. M. (2016).Kepatuhan 5 Momen Hand Hygiene Pada Petugas di Laboratorium Klinik Cito Yogyakarta. 5(1), 16-24. https://doi.org/10.18196/jmmr.510

2.Kepatuhan

Annisa Lazuardi Larasati, C. H. (2020).Penggunaan Desinfektan dan Antiseptik pada Pencegahan Penularan Covid-19 di Masyarakat. 5(3), 137-145. 
Jurnal Kesehatan Karya Husada, Vol 8 No 2 Tahun 2020

PISSN 2337649X/EISSN 2655-8874

Rendi Ariyanto Sinanto, Sitti Nur Djannah "Efektivitas Cuci Tangan Menggunakan Sabun Sebagai Upaya

Pencegahan Infeksi : Tinjauan Literatur” (hal 96-111)

Anwar, A., \& Setyowati, D. L. (2020).Hubungan Sarana Sanitasi, Perilaku Penghuni, dan Kebiasaan Cuci Tangan Pakai Sabun ( CTPS ) oleh Ibu dengan Kejadian Pendek ( Stunting ) pada Batita Usia 624 Bulan di Wilayah Kerja Puskesmas Harapan Baru, Samarinda. 19(1), 7-15.

Citra P Karuru, Theresia I Mogi, L.

S. (2016). Gambaran kepatuhan tenaga kesehatan dalam menerapkan hand hygiene. 4, 25.

Desiyanto, F. A., \& Djannah, S. N.

(2013). Efektivitas Mencuci Tangan Menggunakan Cairan Pembersih Tangan Antiseptik (Hand Sanitizer) Terhadap Jumlah Angka Kuman. Jurnal Kesehatan Masyarakat (Journal of Public Health), 7(2), 75-82. https://doi.org/10.12928/kesmas. v7 i2.1041

Elidahanum Husni, S. R. (2019).

Praktek Cuci Tangan Pakai

Sabun Pada Siswa Sekolah

Dasar 05 Nagari Mungka

Kabupaten Lima Puluh KotA

Processing of Washing use Soap

Wash in Basic School 
Jurnal Kesehatan Karya Husada, Vol 8 No 2 Tahun 2020

PISSN 2337649X/EISSN 2655-8874

Rendi Ariyanto Sinanto, Sitti Nur Djannah "Efektivitas Cuci Tangan Menggunakan Sabun Sebagai Upaya

Pencegahan Infeksi : Tinjauan Literatur” (hal 96-111)

Mukminah, N., Istiarti, V., \& BM, S.

Pencegahan Penyakit Diare di (2016). Faktor Faktor Yang Berhubungan Dengan Praktik Cuci Tangan Pakai Sabun Pada Siswa Sd Di Wilayah Kerja Puskesmas Banyuurip Purworejo. Jurnal Kesehatan Masyarakat (eJournal), 4(5), 354-361.

Nakoe, M. R., S, N. A., \& Mohamad, Y.A. (2020). Perbedaan Efektivitas Hand-Sanitizer Dengan Cuci Tangan Menggunakan Sabun Sebagai Bentuk Pencegahan Covid-19 Difference in the effectiveness of hand-sanitizer by washing hands using soap as a covid-19 preventive measure. 2(2).

Norfai, \& Abdullah. (2018). Efektifitas Penggunaan Sabun Dalam Mencuci Tangan Terhadap Jumlah Kuman. Jurnal Publikasi Kesehatan Masyarakat Indonesia, 5(2), 6570. Notoatmodjo, S. (2012). Promosi Kesehatan dan Perilaku Kesehatan. Jakarta: Rineka Cipta.

Nur, A., Universitas, Y., \& Malang, N. (2020). Pengaruh Pendidikan Kesehatan Menggunakan Team Games Tournament ( TGT ) Terhadap Pengetahuan dan Sikap Cuci Tangan Pakai Sabun Pada Siswa Kelas 5 Sekolah Dasar. 2(2), 145-151.

Radhika, A. (2020). Hubungan Tindakan Cuci Tangan Pakai Sabun Dengan Kejadian Diare Pada Balita Di Rw $\quad X i$ Kelurahan Sidotopo , Kecamatan. 4(1), 16-24.

RI, U. (2009). Undang-Undang Nomor36 Tahun 2009 Tentang Kesehatan. RI, U. (2014). Peraturan Menteri Kesehatan Nomor 3 Tahun 2014 Tentang Sanitasi Total Berbasis Masyarakat.

Risnawaty,G. (2017). Faktor

Determinan Perilaku Cuci Tangan Pakai Sabun (Ctps) Pada Masyarakat Di Tanah Kalikedinding. Jurnal PROMKES, 4(1), 70. https://doi.org/10.20473/jpk.v4.i1 $.2016 .70-81$

Ruíz, A. A. B. (2015). Hubungan kepatuhan cuci tangan enam langkah lima momen perawat dengan kejadian phlebitis di RSUD Dr. Wahidin Sudiro Husodo Mojokerto. 3(2), 54-67. Retrieved from 
Jurnal Kesehatan Karya Husada, Vol 8 No 2 Tahun 2020

PISSN 2337649X/EISSN 2655-8874

Rendi Ariyanto Sinanto, Sitti Nur Djannah “Efektivitas Cuci Tangan Menggunakan Sabun Sebagai Upaya

Pencegahan Infeksi : Tinjauan Literatur" (hal 96-111)

http://repositorio.unan.edu.ni/298

6/1/5624.pdf

Sekarwati, N. (2017). Pengaruh

Pendidikan Kesehatan Terhadap

Perilaku Anak Sekolah Tentang

Cuci Tangan Pakai Sabun (CTPS)

Pada Siswa Di Sekolah Dasar

Negeri Kalasan 1, Kalasan Sleman

Yogyakarta. Jurnal Formil

(Forum Ilmiah) KesMas Respati,

2(April),11-16.

Setkab. (2020). Achmad Yurianto:

Cuci Tangan Lebih Efektif

Gunakan Sabun dan Air

Mengalir.

In Sekretariat

Kabinet Republik Indonesia.

Retrieved from

https://setkab.go.id/achmad-

yurianto-cuci-tangan-lebih-efektif-

gunakan-sabun-dan-air-mengalir/

Setyowatiningsih, L., \& Surati, S.

(2017). Hubungan Higiene

Sanitasi Dengan Kejadian Infeksi

Soil Transmitted Helminths Pada

Pemulung Di Tps Jatibarang.

Jurnal Riset Kesehatan, 6(1), 40.

https://doi.org/10.31983/jrk.v6i1.2

325

Siswanto, S. (2012). Systematic

Review Sebagai Metode Penelitian

Untuk Mensintesis Hasil-Hasil

Penelitian (Sebuah Pengantar).
Buletin Penelitian Sistem

Kesehatan, $\quad 13(4 \quad$ Okt $)$.

https://doi.org/10.22435/bpsk.v13i

$\underline{4}$

Susilo, D. B. (2015). Kepatuhan Pelaksanaan Kegiatan Hand Hygiene Pada Tenaga Kesehatan

Di Rumah Sakit X Surabaya Compliance Implementation Hand Hygiene. Dwi Bagus Susilo, 2(2), 200-204.

Utomo, A. M. dkk. (2013). Hubungan Perilaku Cuci Tangan Pakai Sabun (CTPS) Dengan Kejadian Diare Anak Usia Sekolah Di Sdn 02

Pelemsengir Kecamatan Todanan

Kabupaten Blora. Jurnal

Keperawatan, 6(1), 1-10.

https://doi.org/10.1007/s11340-

009-9279-9

Wahyuni, V. H., Khotimah, S., Liana, D.F., Biologi, P. S., \& Untan, F. (2017). Perbandingan Efektivitas antara Gel Hand Sanitizer dan Tisu Basah Antiseptik terhadap Jumlah Koloni Kuman di Tangan LATAR BELAKANG Penyakit infeksi adalah penyakit yang disebabkan oleh mikroba patogen dan bersifat sangat dinamis . 
Jurnal Kesehatan Karya Husada, Vol 8 No 2 Tahun 2020

PISSN 2337649X/EISSN 2655-8874

Rendi Ariyanto Sinanto, Sitti Nur Djannah "Efektivitas Cuci Tangan Menggunakan Sabun Sebagai Upaya Pencegahan Infeksi : Tinjauan Literatur" (hal 96-111)

Mikroba sebagai mahluk h. Yohana Fresha rihi Hina, samuel Jurnal Cerebellum, 3,808-819.

Wati, N., Yuniar, N., \& paridah, P.

(2017). Pengaruh Intervensi

Penayangan Video Terhadap

Pengetahuan, Sikap Dan

Tindakan Tentang Cuci Tangan

Pakai Sabun Pada Siswa Sdn 10

Kabawo Tahun 2016. Jurnal

Ilmiah Mahasiswa Kesehatan

Masyarakat Unsyiah, 2(5),

186689.

Wulansari, N. T., \& Parut, A. A. (2019). Pengendalian Jumlah Angka Mikroorganisme Pada

Tangan Melalui Proses Hand

Hygiene Control of the Number

of Numbers of Microorganisms

in the Hands Through the Hand

Hygiene Process. 3(1), 7-13.

Yesi Novitasari, Heleni Filtri, S.

(2018). Penyuluhan Program

Perilaku Hidup Bersih Dan Sehat

( Phbs ) Melalui Kegiatan Cuci

Tangan Pakai Sabun Dosen Prodi

Pendidikan Guru Pendidikan

Anak Usia Dini , FKIP , Unilak imanjuntak, I. S. (2016). Perilaku mencuci tangan mahasiswa berasrama dan derajat kebersihan tangan: indikasi program pencegahan infeksi fekal-oral. 2(2),151-158.

Yusnita, Y. (2016). Pengaruh

Pendidikan Kesehatan

Menggunakan Media Poster,Video Dan Leaflet Terhadap Pengetahuan Siswa Dalam Mencuci Tangan Menggunakan Sabun. Jurnal Ilmiah Kesehatan, 5(9). https://doi.org/10.35952/jik.v5i9.2 7

Zubaidi, M. M., Hariyato, T., \& Ardiyani, V. M. (2017). Hubungan Personal Hygene (Cuci Tangan Menggunakan Sabun) dengan Kejadian Penyakit Cacingan pada Anak Kelas I-VI MI Nahdlatul Wathan (NW) Bimbi Desa Rensing Raya Kec. Sakra Barat Kab. Lombok Timur. Nursing New, 2(3),31-37.

Email:yesinovitasari@unilak.ac.i

d Pendahuluan Peningkatan kualitas sumber daya man. 2(1), 44-49. 